\title{
Lasia ruudun takaa - 3D-kierros Suomen lasimuseossa
}

\author{
Lilli Sihvonen'
}

Koronaepidemian vuoksi kaikki Suomen museot sulkivat ovensa 18.3.2020. Tämän jälkeen museot alkoivat vinhaa vauhtia suunnitella näkyvyyttä verkossa. Toteutustapoja on ollut erilaisia näyttelyiden video-opastuksista virtuaalikierroksiin. Suomen lasimuseo on tarjonnut virtuaalikierrosta näyttelyistään jo parin vuoden ajan ${ }^{2}$. Lyhyt kurkistus Suomen lasimuseon 3D-kierrokseen ${ }^{3}$ valottaa niin museon kokoelmaa kuin itse museorakennusta - kuten museokäynnin kuuluukin.

En ole koskaan aiemmin vieraillut Suomen lasimuseossa, en edes sen verkkosivuilla, joten 3D-kierros on vierailuna kaikin puolin ensimmäinen laatuaan. Museon virtuaaliesittely löytyy helposti jo etusivulta klikkaamalla linkkiä "Tutustu virtuaaliseen museoon täällä". Virtuaalinäyttely on kahdessa osassa: 1. kerros omana esittelynään sekä 2. ja 3. kerros samassa esittelyssä. Museon näyttelykerrokset avautuvat virtuaalimatkana alkaen museorakennuksen ulkoa siirtyen sisätilojen näyttelyihin. Näyttelytiloja voi tarkastella myös pohjakarttana sekä nukkekotiversiona, jolloin vierailijalle hahmottuu näyttelytilojen sijoittuminen rakennuksessa paremmin.

Klikkaan itseni ensimmäiseen kerrokseen. Kierros alkaa museon piha-alueelta ja näen, millainen rakennus on ulkoapäin. Kuvissa on kesä, mikä tuntuu miellyttävältä valinnalta. Siirrän kuvaa hiirellä ja tarkastelen ympäristöä eri kohdista. Etenemiskohdat on merkitty maahan valkoisin ympyröin. Menen sisään museorakennuksen aulaan, jossa sijaitsevat museokauppa ja asiakaspalvelu. Lippua ei tällä kertaa tarvitse ostaa. Ensimmäisen kerroksen näyttelyn pääsee aloittamaan kulkemalla asiakaspalvelun vasemmalta puolelta käytävää pitkin. Kyltti ohjeistaa alkuun.

Ensimmäinen kerros esittelee lasin valmistuksen historiaa. Lyhyet näyttelytekstit leijuvat sinisinä ympyröinä ilmassa. Voin myös tutustua varsinaisiin näyttelyteksteihin tarkentamalla niihin hiirellä. Ensimmäisen näyttelykerroksen tunnelma on tiiliseinineen pajamainen. Vitriineissä on lasin valmistukseen käytettyjä esineitä ja työkaluja sekä tietysti lasia.

Siirryn museon 2. ja 3. kerroksiin, joissa sijaitsevat myös vaihtuvien näyttelyjen tilat. Kerrokset avautuvat kirkkaasti valaistuina eriväristen lasien päästessä loistoonsa. Informaatiokohtia tuntuu riittävän. Kierrän kerrokset, ja minua jää harmittamaan, etten pääse vitriinejä lähemmäs, kun punainen lasista valmistettu mäkiauto kiinnittää huomioni. Tarkastellessani kristalleja pääsen paljon lähemmäs esineitä. Viehtymykseni lasiin nousee pintaan.

Vierailen virtuaalinäyttelyssä kolmeen kertaan: ensin kotikoneellani, joka on isonäyttöinen läppäri erillisellä hiirellä, toisella kertaa matkaläppärillä sisäänrakennetun hiiren avulla ja kolmannella kerralla jälleen kotikoneellani. Kotikoneella virtuaalinäyttely toimii paremmin kuin matkaläppärillä, jolla pelkästään hiiren klikkaukset eivät osu kohdilleen ja liikkuminen on jokseenkin turhauttavaa. En saa tarkennettua näyttelyteksteihin, ja suuntavaistonikin menee ajoittain sekaisin. Tietokoneen ruutu alkaa väsyttää. Kehollisena kokemuksena käynti

\footnotetext{
${ }^{1}$ Kirjoittaja on digitaalisen kulttuurin tohtorikoulutettava Turun yliopistossa.

${ }^{2}$ Suomen lasimuseon blogi, suomenlasimuseo.fi 30.4.2020.

${ }^{3}$ Suomen lasimuseon virtuaaliesittely, suomenlasimuseo.fi.
} 


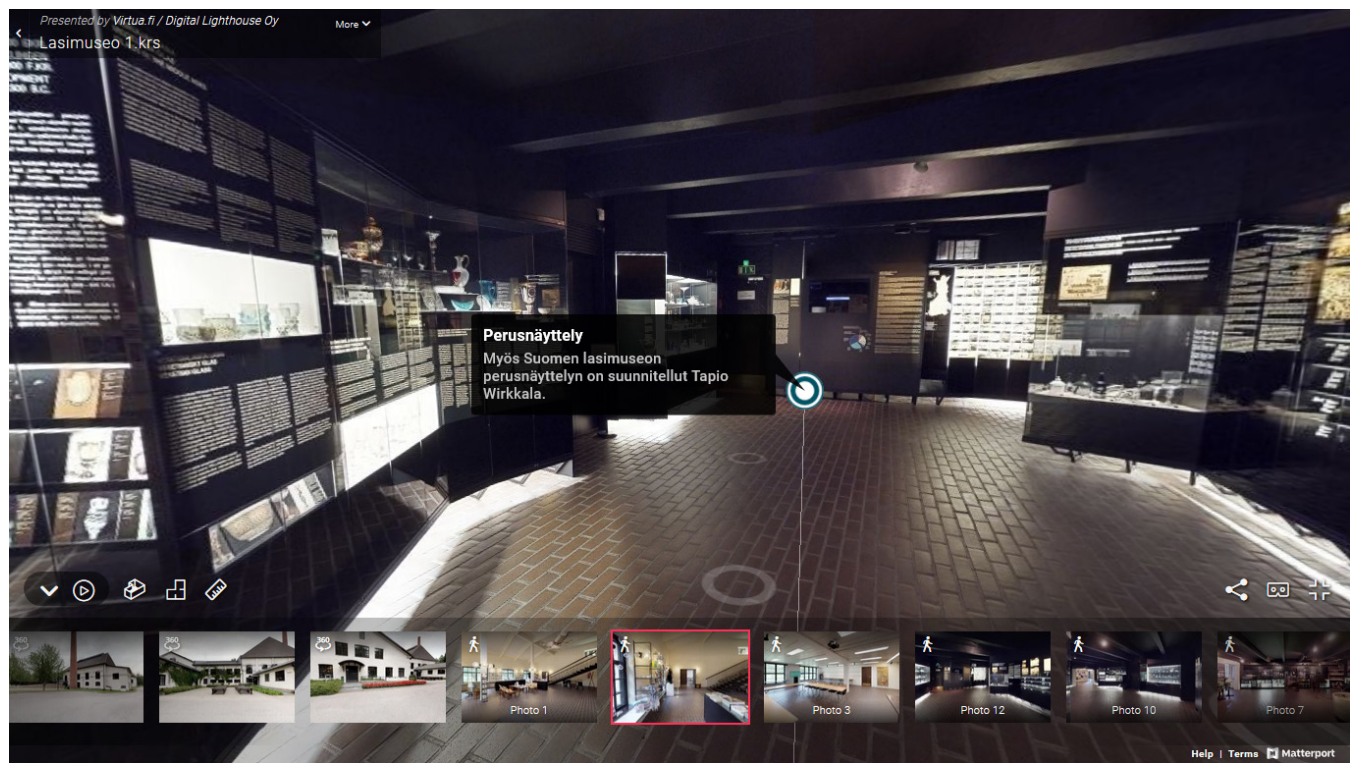

Kuva 1. Kuvakaappaus virtuaalikierroksen ensimmäisestä kerroksesta.

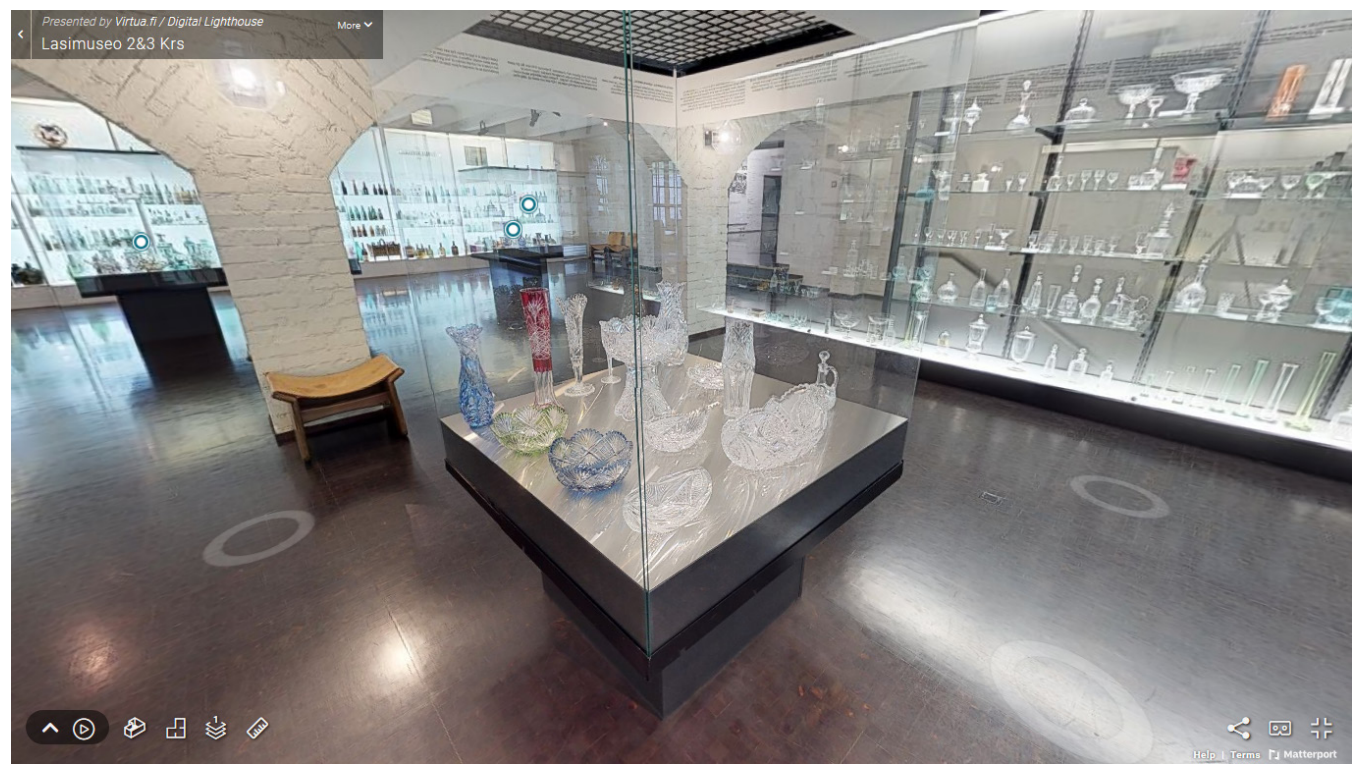

Kuva 2. Kuvakaappaus virtuaalikierroksen 2. ja 3. kerroksesta. 
matkaläppärillä ei ole miellyttävä, koska en hallitse liikkeitäni yhtä hyvin kuin kotikoneella vieraillessani puhumattakaan oikeasta käynnistä. Virtuaaliesittelyssä on mahdollisuus käyttää virtuaalilaseja, joita minulla ei kuitenkaan ole. Jään miettimään, millainen kokemus olisi lasien kanssa.

Visuaalisesti etenkin yläkerran näyttelyt viehättävät lasin ystävää, vaikka toteutus onkin virtuaalinen. Virtuaalikierros saa kävijänsä kiinnostumaan museosta, jolloin ehkä fyysisen käynnin kynnys madaltuu. 2. ja 3. kerroksiin liittyy myös lapsille suunnattuja tehtäviä, jotka aikuinenkin voi innostua tekemään. Virtuaalikierros jää kokonaisuudessaan kuitenkin lyhyemmäksi kuin fyysinen käynti. Käytössä olevat laitteet ja välineet vaikuttavat suuresti siihen, miltä kierros tuntuu. Tyydyn lopulta katselemaan ja tutustumaan museoon hyvin pintapuolisesti. Mikään ei korvaa oikeaa käyntiä.

\section{Lähteet}

Lindfors, Johanna. "Tervetuloa Suomen lasimuseon blogiin!" Suomen lasimuseon blogi 30.4.2020. https:// www.suomenlasimuseo.fi/blogi/2020/4/30/tervetuloa-suomen-lasimuseon-blogiin.

Suomen lasimuseon virtuaaliesittely. 2020. https://www.suomenlasimuseo.fi/virtuaaliesittely. 